\title{
HUBUNGAN GAYA HIDUP DAN POLA MAKAN DENGAN KEJADIAN DIABETES MELLITUS DI RUMAH SAKIT BHAYANGKARA KOTA MAKASSAR
}

\section{The Relationship Between Lifestyle And Dietary Habit Towards Diabetes Mellitus Cases At Bhayangkara Hospital, Makassar City}

\author{
Suryanti S ${ }^{1}$, Sumardi Sudarman ${ }^{2}$, Aswadi $^{3}$ \\ Fakultas Kesehatan Masyarakat, Universitas Pancasakti, Makassar
}

Korespondensi: suriyanti.dokkes@gmail.com

\begin{abstract}
ABSTRAK
Diabetes Mellitus (DM) adalah penyakit metabolik yang bersifat kronik, ditandai dengan meningkatnya kadar glukosa darah sebagai akibat dari adanya gangguan penggunaan insulin, sekresi insulin, atau keduanya. Penyakit Diabetes Mellitus (DM) merupakan ancaman serius bagi pembangunan kesehatan dan pertumbuhan ekonomi nasional, karena itu pengendaliannya perlu dilakukan dengan sungguh-sungguh, secara komprehensif dan terintegrasi dengan memberikan perhatian melalui pengendalian penyakit tidak menular seperti tidak merokok, diet sehat dan aktivitas sehat yang dimulai sejak janin sampai dewasa tua. Penelitian ini bertujuan untuk mengetahui hubungan gaya hidup dan pola makan dengan kejadian diabetes mellitus di Rumah Sakit Bhayangkara Kota Makassar. Jenis penelitian yang digunakan adalah survey analitik dengan desain cross sectional study. Sampel dalam penelitian ini adalah sebanyak 64 responden, yang diperoleh dengan teknik simple random sampling. Hasil penelitian menunjukkan menunjukkan bahwa ada hubungan kebiasaan merokok $(\mathrm{p}=0.042)$, aktivitas fisik $(\mathrm{p}=0,027)$, dan pola makan $(\mathrm{p}=0.010)$ dengan kejadian diabetes mellitus. Tidak ada hubungan kebiasaan mengkonsumsi minuman beralkohol $(\mathrm{p}=0.628)$ dengan kejadian diabetes mellitus. Untuk itu, diharapkan kepada masyarakat untuk memperbaiki gaya hidup dengan tidak merokok, melakukan aktivitas fisik secara teratur, serta menjaga pola makan yang baik.
\end{abstract}

Kata kunci: Gaya hidup, pola makan, diabetes mellitus.

\section{ABSTRACT}

Diabetes Mellitus (DM) is a chronic metabolic disease characterized by increased blood glucose levels as a result of impaired insulin use, insulin secretion, or both. Diabetes Mellitus (DM) is a serious threat to health development and national economic growth, therefore its control needs to be carried out seriously, comprehensively and integratedly by giving attention through controlling non-communicable diseases such as not smoking, a healthy diet and starting healthy activities. from fetus to old adulthood. This study aims to determine the relationship between lifestyle and diet with the incidence of diabetes mellitus in Bhayangkara Hospital, Makassar City. This type of research is analytic survey with cross sectional study design. The sample in this study were 64 respondents, which were obtained by simple random sampling technique. The results showed that there was a relationship between smoking habits ( $p$ $=0.042)$, physical activity $(p=0.027)$, and diet $(p=0.010)$ with the incidence of diabetes mellitus. There was no relationship between the habit of consuming alcoholic drinks $(p=0.628)$ with the incidence of diabetes mellitus. Therefore, it is hoped that the community will improve their lifestyle by not smoking, doing regular physical activity, and maintaining a good diet.

Keywords: Lifestyle, dietary habit, diabetes mellitus.

Suryanti S, Sumardi Sudarman, Aswadi 


\section{PENDAHULUAN}

Diabetes Mellitus (DM) adalah penyakit metabolik yang bersifat kronik, ditandai dengan meningkatnya kadar glukosa darah akibat dari adanya ganguuan penggunaan insulin, sekresi insulin, atau keduanya. Penyakit Diabetes Mellitus (DM) merupakan ancaman serius bagi pembangunan kesehatan dan pertumbuhan ekonomi nasional, karena itu pengendaliannya perlu dilakukan dengan sungguh-sungguh, secara komprehensif dan terintegrasi dengan memberikan perhatian melalui pengendalian penyakit tidak menular seperti tidak merokok, diet sehat dan aktivitas sehat yang dimulai sejak janin sampai dewasa tua (Smeltzer, 2010 dalam Meta, R, Rostiodertina, G, 2018).

Penyakit ini, merupakan salah satu dari 10 penyakit penyebab utama kematian di dunia, yang menyebabkan 1,5 juta $(2,7 \%)$ kematian pada tahun 2012. Saaat ini terdapat 171 juta penderita Diabetes Mellitus di seluruh dunia, dan diperkirakan akan meningkat dua kali yaitu 366 juta pada tahun 2030 (WHO, 2014). Prevalensi Diabetes Mellitus di Indonesia saat pada tahun 2000 mencapai 8.426.000 kasus dan diproyeksi akan mencapai 21.257.000 kasus pada tahun 2030. Artinya, akan terjadi kenaikan 3 kali lipat dalam kurun waktu 30 tahun. Gaya hidup dan faktor lingkungan merupakan faktor yang dapat meningkatkan angka kesakitan DM (Ridwan, 2007 dalam Wirda Faswita, 2019).

Peningkatan kasus diabetes mellitus terus meningkat setiap tahunnya dan tersebar hampir di seluruh provinsi di Indonesia. Provinsi Jawa Timur menjadi provinsi dengan prevalensi diabetes mellitus tertinggi yaitu mencapai 2,6\% pada tahun 2018, meningkat dari tahun 2013 yaitu sebesar 2,1\%. Berdasarkan konsensus Perkeni 2015 pada penduduk $\geq 15$ tahun, prevalensi diabetes mellitus meningkat sebanyak 10,9\% (Kemenkes RI, 2018 dalam Sasmiyanto, 2019).

Sulawesi Selatan merupakan salah satu provinsi di Indonesia dengan prevalensi diabetes mellitus cukup tinggi. Berdasarkan hasil Riskesdas 2013, prevalensi diabetes mellitus yang didiagnosis dokter sebanyak 1,6\% dan tertinggi berada di Kabupaten Pinrang yaitu mencapai 2,8\%. Selanjutnya diikuti oleh Kota Makassar sebagai Ibukota Provinsi Sulawesi Selatan, yang mencapai 2,5\%. Tingginya angka prevalensi DM di Kota Makassar juga terlihat pada peningkatan jumlah pasien stroke yang berkunjung ke Rumah Sakit Bhayangkara. Pada tahun 2017 , tercatat sebanyak 1.345 pasien yang berkunjung atau berobat di Rumah Sakit Bhayangkara dan meningkat pada tahun 2018 yaitu sebanyak 1.554 pasien.

Penyakit DM merupakan penyakit degeneratif yang umumnya disebabkan oleh gaya hidup yang tidak sehat (Safitri et al., 2021). Penelitian ini bertujuan untuk mengetahui hubungan gaya hidup dengan kejadian diabetes mellitus di Rumah Sakit Bhayangkara. 


\section{BAHAN DAN METODE}

Jenis penelitian adalah survey analitik dengan rancangan cross sectional study. Penelitian ini dilakukan di Rumah Sakit Bahayangkara pada Oktober 2020. Populasi dalam penelitian ini adalah seluruh masyarakat yang datang berobat di Rumah Sakit Bhayangkara pada periode Januari - April 2020 yaitu sebanyak 193 pasien, sedangkan sampel yang diambil sebanyak 64 responden dihitung menggunakan rumus Lemeshow (1991). Teknik pengambilan sampel yang digunakan adalah simple random sampling. Data dikumpulkan melalui wawancara langsung menggunakan kuesioner yang disusun sendiri untuk mengukur variabel. Analisis data dilakukan secara univariat dan bivariat menggunakan uji chi square. Data yang telah diolah kemudian disajikan dalam bentuk tabel disertai dengan narasi.

\section{HASIL}

\section{Univariat}

Karakteristik responden dalam penelitian ini berdasarkan distribusi umur, jenis kelamin, pendidikan dan pekerjaan (Tabel. 1). Sedangkan variabel dalam penelitian ini meliputi kebiasaan merokok, aktivitas fisik, kebiasaan mengkonsumsi alkohol, pola makan, dan kejadian diabetes (Tabel. 2). Tabel.1 menunjukkan bahwa responden paling banyak berasal dari kelompok umur antara 51-60 tahun $(34,4 \%)$ dan berjenis kelamin perempuan (56,3\%). Dari kategori tingkat pendidikan, paling banyak responden memiliki tingkat pendidikan sampai Sarjana yaitu sebanyak $53,1 \%$. Untuk bidang pekerjaan, sebanyak 18 responden $(28,1 \%)$ merupakan ibu rumah tangga.

Berdasarkan Tabel. 2, dapat dilihat bahwa responden yang memiliki kebiasaan merokok dengan risiko tinggi sebanyak 15 $(23,4 \%)$ responden, aktivitas fisik dengan risiko tinggi sebanyak $16(25,0 \%)$ responden, kebiasaan mengkonsumsi alkohol dengan risiko tinggi sebanyak $8 \quad(12,5 \%)$ responden. Berdasarkan pola makan responden, sebanyak 46 (71,9\%) responden dengan pola makan normal. Sedangkan berdasarkan kejadian diabetes mellitus, terdapat $39(60,9 \%)$ penderita.

\section{Bivariat}

Hasil analisis bivariat yang menilai hubungan variabel independen (kebiasaan merokok, aktivitas fisik, kebiasaan mengkonsumsi alkohol, dan pola makan) dengan variabel dependen (kejadian Diabetes Melitus).

Tabel 3 menunjukkan bahwa dari 15 responden yang memiliki kebiasaan merokok risiko tinggi, sebanyak $13(20,3 \%)$ yang menderita DM, dan $2(3,1 \%)$ responden tidak menderita DM. Sedangkan dari 49 responden yang memiliki kebiasaan merokok resiko rendah, terdapat 26 responden $(40,6 \%)$ yang menderita DM, dan 23 responden (35,9\%) yang tidak menderita DM. 


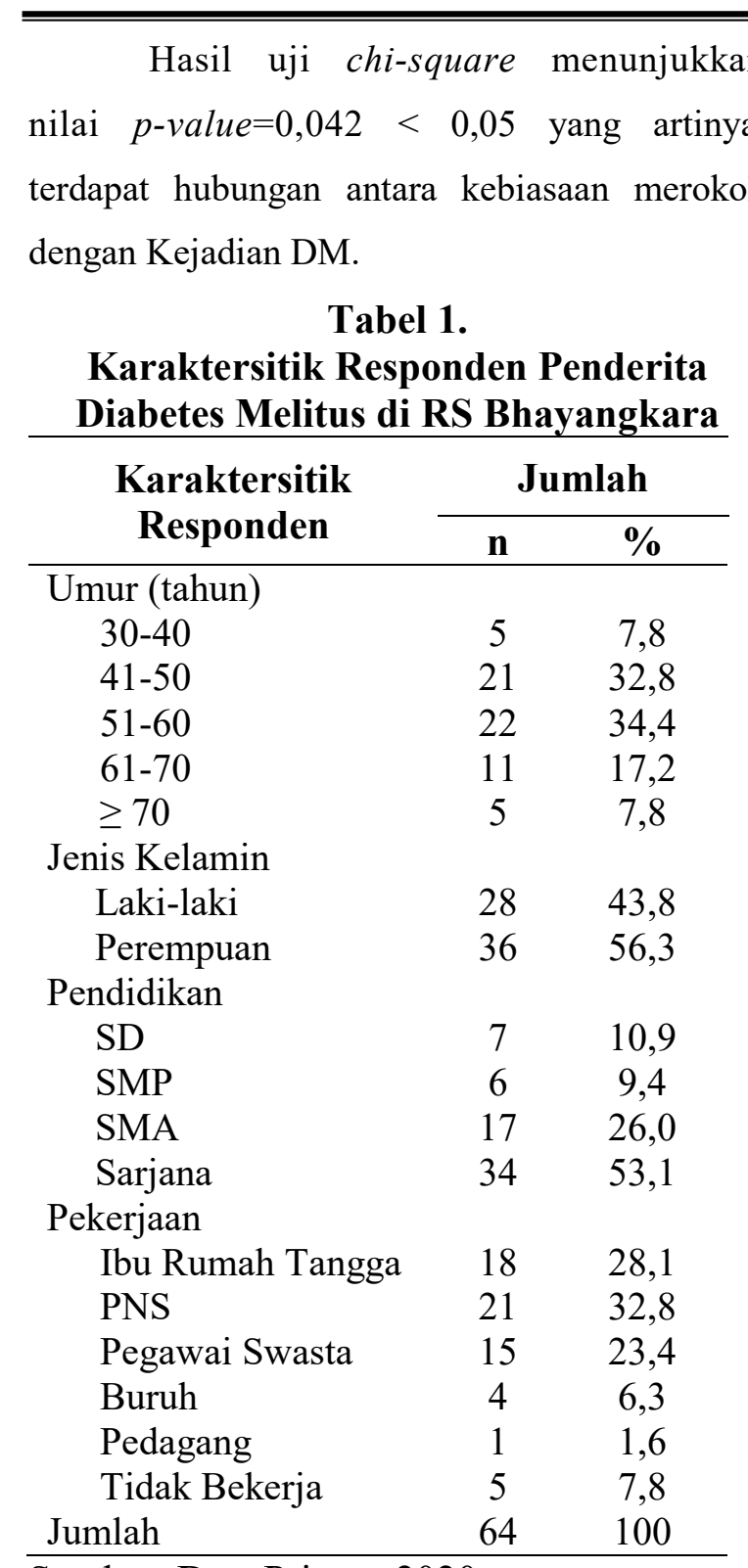

Sumber: Data Primer, 2020

Berdasarkan aktivitas fisik responden terlihat bahwa dari 16 responden dengan resiko tinggi, terdapat 14 responden $(21,9 \%)$ yang menderita DM, dan 2 responden $(3,1 \%)$ yang tidak menderita DM. Sedangkan dari 48 responden dengan resiko rendah, terdapat 25 responden $(39,0 \%)$ yang menderita DM, dan 23 responden $(35,9 \%)$ yang tidak menderita DM.

Hasil uji chi-square menunjukkan nilai $p$ value $=0,035<0,05$ yang artinya, terdapat hubungan antara aktivitas fisik responden dengan kejadian DM.

Tabel 2.

Distribusi Responden Berdasarkan Variabel Penelitian

\begin{tabular}{lcc}
\hline \multirow{2}{*}{ Variabel } & \multicolumn{2}{c}{ Jumlah } \\
\cline { 2 - 3 } & $\mathbf{n}$ & $\mathbf{\%}$ \\
\hline Kebiasaan Merokok & & \\
$\quad$ Risiko Tinggi & 15 & 23,4 \\
$\quad$ Risiko Rendah & 49 & 76,6 \\
Aktivitas Fisik & & \\
$\quad$ Risiko Tinggi & 16 & 25,0 \\
$\quad$ Risiko Rendah & 48 & 75,0 \\
Kebiasaan Konsumsi & & \\
Alkohol & & \\
$\quad$ Risiko Tinggi & 8 & 12,5 \\
$\quad$ Risiko Rendah & 56 & 87,5 \\
Pola Makan & & \\
$\quad$ Normal & 46 & 71,9 \\
$\quad$ Lebih & 18 & 28,1 \\
Diabetes Melitus & & \\
$\quad$ Menderita & 39 & 60,9 \\
$\quad$ Tidak Menderita & 25 & 39,1 \\
Jumlah & 64 & 100 \\
\hline Sumb Data Primer, 2020 &
\end{tabular}

Sumber: Data Primer, 2020

Berdasarkan kebiasaan mengkonsumsi alkohol responden, terlihat bahwa dari 8 responden yang memiliki kebiasaan dengan resiko tinggi, terdapat 6 responden $(9,4 \%)$ yang menderita DM dan 2 responden (3,1\%) yang tidak menderita DM. Hasil uji chi-square menunjukkan nilai $p$-value $=0,000>0,05$. Artinya, tidak terdapat hubungan antara kbiasaan mengkonsumsi alkohol dengan kejadian DM.

Berdasarkan pola makan responden terlihat bahwa dari 46 responden dengan pola 
makan normal, terdapat 23 responden $(35,9 \%)$ yang menderita DM dan 23 responden (35,9\%) yang tidak menderita DM. Sedangkan dari 18 responden dengan pola makan lebih, terdapat 16 responden $(25,0 \%)$ yang menderita $\mathrm{DM}$ dan 2 responden $(3,9 \%)$ yang tidak menderita DM. Hasil uji chi square menunjukkan nilai $\mathrm{p}=0.010$ $<0.05$. Artinya, terdapat hubungan antara pola makan dengan kejadian DM.

Tabel 3.

Analisis Hubungan Variabel Independen dengan Kejadian Diabetes Melitus Di Rumah Sakit Bhayangkara

\begin{tabular}{|c|c|c|c|c|c|c|c|}
\hline \multirow{3}{*}{ Variabel } & \multicolumn{4}{|c|}{ Diabetes Melitus } & \multirow{2}{*}{\multicolumn{2}{|c|}{ Total }} & \multirow{3}{*}{ P Value } \\
\hline & \multicolumn{2}{|c|}{ Menderita } & \multicolumn{2}{|c|}{ Tidak Menderita } & & & \\
\hline & $\mathbf{n}$ & $\%$ & $\mathbf{n}$ & $\%$ & $\mathbf{n}$ & $\%$ & \\
\hline \multicolumn{8}{|c|}{ Kebiasaan Merokok } \\
\hline Risiko Tinggi & 13 & 20,3 & 2 & 3,1 & 15 & 23,4 & \multirow{2}{*}{0,042} \\
\hline Risiko Rendah & 26 & 40,6 & 23 & 35,9 & 49 & 76,6 & \\
\hline \multicolumn{8}{|l|}{ Aktivitas Fisik } \\
\hline Risiko Tinggi & 14 & 21,9 & 2 & 3,1 & 16 & 25,0 & \multirow{2}{*}{0,027} \\
\hline Risiko Rendah & 25 & 39,0 & 23 & 35,9 & 48 & 75,0 & \\
\hline \multicolumn{8}{|c|}{ Kebiasaan Konsumsi } \\
\hline \multicolumn{8}{|c|}{ Alkohol } \\
\hline Risiko Tinggi & 6 & 9,4 & 2 & 3,1 & 8 & 12,5 & \multirow{2}{*}{0,332} \\
\hline Risiko Rendah & 33 & 51,6 & 23 & 35,9 & 56 & 87,5 & \\
\hline \multicolumn{8}{|l|}{ Pola Makan } \\
\hline Normal & 23 & 35,9 & 23 & 35,9 & 46 & 71,9 & \multirow{2}{*}{0,010} \\
\hline Lebih & 16 & 25,0 & 2 & 3,9 & 18 & 28,1 & \\
\hline
\end{tabular}

Sumber: Data Primer, 2020

\section{PEMBAHASAN}

\section{Hubungan Kebiasaan Merokok Dengan Kejadian DM}

Rokok adalah salah satu produk tembakau yang dimaksudkan untuk dibakar dan dihisap dan dihirup asapnya, termasuk rokok kretek, rokok putih, cerutu atau bentuk lainnya yang dihasilkan dari tanaman Nicotiana Tabacum. Nikotin dalam rokok resistensi insulin dan dapat menurunkan sekresi insulin pada pankreas (Halim C, 2017).

Kebiasaan merokok berhubungan secara mencolok dengan bertambahnya risiko terjadinya diabetes dan keuntungan berhenti merokok hanya nampak setelah 5 tahun berhenti, bahkan risikonya pun bisa seperti bukan perokok hanya setelah 20 tahun (UNDIP, 2007).

Hasil penelitian Dr. Carole Willi dkk menunjukkan bahwa perokok berat yang menghabiskan 20 batang rokok sehari memiliki 
risiko terserang $\mathrm{DM} \quad 62 \%$ lebih tinggi dibandingkan dengan orang yang tidak merokok (Pudjaji, 2009). Selain itu, kebiasaan merokok pada penderita diabetic dapat meningkatkan dan mempertebal plasma dinding pembuluh darah (aterosklerosis) yang dapat menyebabkan komplikasi kardovaskuler (Hartini S, 2009).

Hasil penelitian ini sesuai dengan hasil penelitian yang dilakukan Radio (2011) dengan judul Faktor-Faktor Yang Berhubungan Dengan Kejadian Diabetes Melitus Tipe 2 (Studi Kasus di Poliklinik Penyakit Dalam Rumah Sakit Dr. Kariadi), dimana hasil analisis tabulasi silang didapatkan odds ratio (OR) sebesar 2,9 dan nilai $\mathrm{p}=0,08$. Hal ini menunjukkan bahwa orang yang memiliki kebiasaan merokok memiliki risiko 3 kali terjadinya DM tipe 2 dibandingkan dengan orang yang tidak memiliki kebiasaan merokok meskipun secara statistik tidak bermakna.

\section{Hubungan Aktifitas Fisik Dengan Kejadian DM}

Aktivitas fisik adalah setiap gerakan tubuh yang terjadi akibat kontraksi otot skeletal yang meningkatkan pengeluaran energi.Aktivitas fisik ini dapat berupa aktivitas di tempat kerja, aktivitas di perjalanan, aktivitas di rumah, dan aktivitas di waktu luang (Quarino, 2014).

Aktivitas fisik secara teratur menambah sensitivitas insulin dan menambah toleransi glukosa. Aktivitas fisik mempunyai efek menguntungkan pada lemak tubuh, tekanan darah, dan distribusi lemak tubuh/ berat badan, yaitu pada aspek ganda 'sindroma metabolic kronik', sehingga juga mencegah penyakit kardiovaskuler. Dengan demikian olahraga memiliki efek protektif yang dapat dicapai dengan pengurangan berat badan melalui bertambahnya aktivitas fisik (Darmono, dkk, 2007).

Dalam pengelolaan DM, aktivitas fisik merupakan salah satu dari empat pilar. Aktivitas minimal yang dibutuhkan oleh semua orang termasuk diabetes meliputi aktivitas atau kegiatan sehari-hari, seperti bangun tidur, memasak, berpakaian, mencuci, makan bahkan tersenyum. Berangkat kerja, bekerja, berbicara, berfikir, tertawa, merencanakan kegiatan esok, kemudian tidur. Semua kegiatan tadi tanpa disadari oleh diabetisi, telah sekaligus menjalankan pengelolaan terhadap DM seharihari (Musyayadah, 2017).

Aktivitas fisik yang dilakukan secara teratur dapat menambah sensitifitas insulin. Prevalensi diabetes mellitus mencapai 2-4 kali lipat terjadi pada individu yang kurang aktif dibandingkan dengan individu yang aktif. Semakin kurang aktivitas fisik, maka semakin mudah seseorang terkena diabetes. Olahraga atau aktivitas fisik dapat membantu mengontrol berat badan. Glukosa dalam darah akan dibakar menjadi energi, sehingga sel-sel tubuh menjadi lebih sensitif terhadap insulin. Selain itu, aktivitas fisik yang teratur juga dapat melancarkan peredaran darah, dan menurunkan faktor risiko terjadinya diabetes mellitus (Suiraoka, 2012). 


$$
\text { Sejalan dengan penelitian yang }
$$

dilakukan Musyayadah (2017) Di RSUP Dr

Wahidin Sudirohusodo Dan RS Universitas

Hasanuddin Makassar, yang menunjukkan bahwa ada hubungan aktivitas fisik (pvalue $=0,000)$ dengan kejadian diabetes mellitus .

Penelitian yang sama dilakukan oleh Larasati (2013) menunjukkan adanya hubungan yang bermakna antara aktivitas fisik dengan kadar HbA1c. Kesimpulan hasil penelitian tersebut menyatakan bahwa aktivitas fisik yang dilakukan bila ingin mendapatkan hasil yang baik harus memenuhi syarat yaitu dilaksanakan minimal 3 sampai 4 kali dalam seminggu serta dalam kurun waktu minimal 30 menit dalam sekali beraktivitas. Aktivitas fisik tidak harus aktivitas berat, cukup dengan berjalan kaki di pagi hari sambil menikmati pemandangan selama 30 menit atau lebih sudah termasuk dalam kriteria aktivitas yang baik. Namun, apabila setelah melakukan aktivitas fisik dilanjutkan dengan beristirahat dalam jangka waktu yang cukup lama maka aktivitas fisik yang dilakukan tidak akan banyak mempengaruhi kadar HbAlc-nya karena pasien diabetes tidak dianjurkan untuk banyak beristirahat.

\section{Hubungan Mengonsumsi Alkohol Dengan Kejadian DM}

Alkohol banyak menimbulkan masalah kesehatan jika dikonsumsi, apalagi di konsumsi secara berlebihan. Salah satu masalah kesehatan yang ditemukan adalah adanya penurunan kadar gula darah dalam tubuh. Menurut Joewana (2005), Alkohol juga dapat menyebabkan terjadinya hipoglikemia (karena menghambat proses glukoneogenesis). Hipoglikemi alkohol terjadi akibat dari puasa yang berkepenjangan dan konsumsi alkohol berlebih, ketika cadangan glikogen hati habis dan alkohol menghambat glukoneogenesis.

Metabolisme alkohol menyebabkan peningkatan kadar NADH dalam tubuh. Peningkatan kadar NADH dapat menyebabkan terganggunya proses glukoneogenesis. NADH yang tinggi menghambat konversi laktat menjadi piruvat. Piruvat dibutuhkan untuk proses glukoneogenesis (Kandi, 2014 dalam Intan, A 2017).

Efek alkohol pada kadar gula darah, tidak hanya tergantung pada alkohol yang dikonsumsi, tapi juga berhubungan dengan asupan makanan. Proses untuk mencerna alkohol yang ada di dalam tubuh kita itu sama dengan proses saat tubuh kita mencerna lemak. Alkohol yang konsumsi akan meningkatkan kadar gula dalam darah karena alkohol akan mempengaruhi kinerja hormon insulin (Tjokroprawiro, 2011).

Karbohidrat merupakan kandungan yang banyak ditemui dalam alkohol sehingga pada saat dikonsumsi, pankreas akan mengeluarkan lebih banyak hormon insulin sehingga meningkatkan kadar gula dalam darah. Hasil penelitian ini sesuai dengan hasil penelitian yang telah dilakukan oleh Intan Ambarwati (2017) di PKBM Negeri 33 Malaka Jakarta Timur.Hasil 
penelitian menunjukan bahwa terdapat hubungan yang signifikan antara konsumsi alkoholisme berat dengan hipoglikemi dengan $\mathrm{P}$ value $=$ $0,000(\alpha<0,05)$.

Hasil penelitian ini juga diperkuat dengan hasil penelitian yang dilakukan Fauza (2015) pada penderita diabetes mellitus usia 4564 tahun, dimana hasil penelitian menunjukkan bahwa variabel yang mempengaruhi kejadian diabetes mellitus adalah konsumsi alkohol $(\mathrm{p}=0.016)$

\section{Hubungan Pola Makan Dengan Kejadian DM} Pola makan dapat diartikan sebagai suatu kebiasaan menetap dalam hubungan dengan konsumsi makan yaitu berdasarkan bahan makanan: makanan pokok, sumber protein, sayur, buah dan berdasarkan frekuensi harian, mingguan, pernah dan tidak pernah sama sekali. Dalam hal pemilihan makanan dan waktu makan manusia dipengaruhi oleh usia, selera pribadi, kebiasaan, budaya dan sosial ekonomi (Almatsier, 2007). Fenomena yang terjadi dimasyarakat seiring dengan pergeseran zaman menyebabkan perubahan pola makan yang alami menjadi modern. Pilihan menu makanan dan cara hidup yang kurang sehat semakin menyebar keseluruh lapisan masyarakat, sehingga meyebabkan terjadinya penyakit degenarative, salah satunya Diabetes Melitus (Bustan, 2007 dalam Putri Dafriania, 2017).

Frekuensi makan pada setiap orang berbeda-beda. Pada kondisi normal setiap orang diharuskan makan 3 kali sehari. Seseorang yang tidak mampu mengatur pola makan dalam makanan sehari-hari akan lebih mudah terkena penyakit dibandingkan dengan yang berhati-hati dalam mengkonsumsi makanan. Pola makan yang salah dapat mengakibatkan kurang gizi atau kelebihan berat badan. Kedua hal tesebut dapat meningkatkan risiko terkena diabetes. Kurang gizi (malnutrisi) dapat mengganggu fungsi pankreas dan mengakibatkan gangguan sekresi insulin. Sedangkan kelebihan berat badan dapat mengakibatkan gangguan kerja insulin (Suiraoka, 2012).

Hasil penelitian ini sesuai dengan hasil penelitian yang dilakukan Susanti, dkk (2018) di Puskesmas Tembok Dukuh Surabaya, dimana hasil penelitian menunjukkan bahwa ada hubungan antara pola makan dengan kadar gula darah pada penderita Diabetes Mellitus ( $p$ value $=0,000$ ). Hasil penelitian ini juga diperkuat dengan hasil penelitian yang dilakukan Putri Dafriani (2017) di Poliklinik Penyakit Dalam RSUD dr. Rasidin Padang, dimana hasil penelitian menunjukkan bahwa ada hubungan pola makan dengan kejadian DM ( $p$ value $=0,047)$.

\section{KESIMPULAN DAN SARAN}

Dari hasil penelitian dan pembahasan yang dilakukan, disumpulkan bahwa ada hubungan kebiasaan merokok ( $p$-value $=0,042)$, aktivitas fisik ( $p$-value $=0,027)$, pola makan 


\section{JURNAL Promotif Preventif}

responden $(p$-value $=0,010)$ dengan kejadian

Diabetes Melitus. Dan tidak ada hubungan kebiasaan mengkonsumsi alkohol responden ( $p$ value $=0,628$ ) dengan kejadian DM.

Diharapakan bagi masyarakat agar mengatur pola makan dengan frekuensi makan yang normal 2 - 3 kali sehari, dan memperbaiki gaya hidup dengan melakukan aktivitas fisik sevara teratur serta tidak merokok.

\section{DAFTAR PUSTAKA}

Fauza, Andira. 2015. "Hubungan Konsumsi Alkohol Dan Obesitas Dengan Kejadian Diabetes Mellitus Usia 45-64 Tahun Di Pulau Sulawesi “ Program Studi Ilmu Gizi Fakultas Ilmu-ilmu Kesehatan Universitas Esa Unggul Jakarta Barat.

Intan Ambarwati, 2017. "Hubungan Konsumsi Alkohol Dengan Kejadian Hipoglikemi Pada Peserta Didik Remaja Pkbm Negeri 33 Malaka Jakarta Timur". Keperawatan, Fakultas Ilmu Keperawatan Universitas Muhammadiyah Jakarta

Kemenkes RI. 2013. Riset Kesehatan Dasar (RISKESDAS) 2013. Jakarta: Kementrian Kesehatan RI.

Musyayadah, 2017. "Faktor Yang Berhubungan Dengan Kejadian Diabetes Mellitus Di Rsup Dr Wahidin Sudirohusodo Dan Rs Universitas Hasanuddin Makassar
"(On-line) FKM. Univesitas Hasanuddin Makassar.

Perkenni. 2011. Meningkatnya angka kejadian DM diseluruh populasi penduduk dunia.www. perkenni.go.id diakes pada tanggal 20 januari 2015

Quarino, A. 2014. "Perbandingan Rerata Jumlah Langkah Sebagai Penanda Aktivitas Fisik antara Pekerja dengan Sindroma Metabolik dan Tanpa Sindroma Metabolik". Jakarta: Fakultas Kedokteran Universitas Indonesia

Radio, 2011. Faktor-Faktor yang Berhubungan Dengan Kejadian DM Tipe 2 Di RS Dr. Kariadi Dipenogoro (on-line)

Sasmiyanto, 2019. "Hubungan Perilaku Kesehatan dengan Kadar Gula Darah dan Kualitas Hidup Pasien Diabetes". Universitas Muhammadiyah Jember

Suiraoka. 2012. "Penyakit Degeneratif, Mengenal, Mencegah dan Mengurangi Faktor Risiko 9 Penyakit Degeneratif”. Yogyakarta: Nuha Medika

Wirda Faswita, 2019. "Gambaran Kualitas Hidup Penderita Diabetes Melitus Tipe 2 Di Rsud.Dr. Rm Djoelham Kota Binjai Tahun 2019 “. Akademi Keperawata Sehat Binjai

Safitri, E., Sudarman, S. and Nur, N.H. (2021) 'Eating Pattern Relationship With Events Diabetes Mellitus Type 2 In The Working Area Of The Pertiwi Health Center, Makassar City'. Pancasakti Journal of Public Health Science and Research, 1(1), pp. 30-38. DOI: 10.47650/pjphsr.v1i1.209. 